\begin{tabular}{|l|l|}
\hline Journal Code: REEL & Proofreader: Mony \\
\hline Article No: REEL12059 & Delivery date: 21 Jan 2014 \\
\hline Page Extent: 10 & \\
\hline
\end{tabular}

RECIEL ••(••) 2014. ISSN 2050-0386

\title{
Reviving Rylands: How the Doctrine Could Be Used to Claim Compensation for Environmental Damages Caused by Fracking
}

\author{
Róisín Áine Costello
}

\begin{abstract}
Contemporary societies are characterized by complex interdependence, with industrial activity increasingly having the potential to cause effects beyond local and national borders. Courts have previously illustrated that liability for injurious action must lie with the individual who created the risk of damage under the common law rule of Rylands v. Fletcher. Having fallen out of favour in the twentieth century, this article proposes a re-articulation of the rule to cover situations in modern society in which invasive methods are used in the extraction of volatile fuels from the earth, specifically in the case of 'fracking'. The article examines recent rulings from the United States and the United Kingdom, as well as precedent from the United Kingdom and Ireland to establish the manner in which the rule of Rylands v. Fletcher might be successfully rearticulated in the context of contemporary common law jurisdictions - specifically focusing on Ireland as a means for redressing environmental damage.
\end{abstract}

\section{INTRODUCTION}

In an increasingly interdependent society, ultimate liability for injury or damage arising from industry should lie with those who engage in the potentially injurious activity. Common law courts have previously illustrated that, insofar as society approves of the distribution of burdens of responsibility to certain individuals or groups, liability for injurious action must lie with the individual who created the risk of damage. However, the increasingly invasive methods used in the extraction of volatile fuels from the earth, particularly through 'fracking', pose significant challenges to balancing the protection of the environment and the property rights of individuals with conditions that do not stifle industry.

This article will examine attempts to regulate this new industry and will seek to locate 'fracking' within the constellation of activities with potentially negative environmental implications that should be accorded strict liability status under the rule in Rylands $v$. Fletcher.

${ }^{1}$ Rylands v. Fletcher, [1868] UKHL 1.

(c) 2014 John Wiley \& Sons Ltd, 9600 Garsington Road, Oxford OX4 2DQ, UK and 350 Main Street, Malden, MA 02148, USA.
The article will undertake a comparative evaluation of the laws and regulations governing fracking in place in the common law jurisdictions in which Rylands first emerged and enjoyed general application - namely the United Kingdom, Australia and Ireland.

The article first defines fracking and examines its emergence and current use both in the United States and Europe. It then outlines the emergence of the rule in Rylands $v$. Fletcher, its uses and adoption throughout common law jurisdictions and its decline in use during the late twentieth century. The article next considers the case of Dimock, Pennsylvania, as a specific example of situations in which fracking may lead to a cause of action under the rule in Rylands. Finally, the article turns to Ireland as an example of the current legal and regulatory context of fuel extraction laws in common law jurisdictions, and speculates as to the potential revival of the rule in Rylands to cover damages sustained as a result of the escape of fracking fluids in Ireland and, thus in other common law jurisdictions.

\section{WHAT IS FRACKING?}

Hydraulic fracturing or 'fracking' involves the injection of large quantities of water, sand and chemicals (usually a significant quantity of which is methane) deep into the ground at high pressure in order to force small, dispersed gas deposits to the surface where they are extracted and stored. ${ }^{2}$ Fracking has proved controversial and has been the subject of study in respect to its potential environmental consequences. ${ }^{3}$ Such consequences potentially include pollution of groundwater

\footnotetext{
${ }^{2}$ For a brief explanation of fracking, see BBC, 'What is Fracking: The Process Explained in 15 Seconds', BBC News (13 December 2012), found at: <http://www.bbc.co.uk/news/uk-20710481>. Gas extracted through fracking is commonly referred to as 'shale gas'.

${ }^{3} \mathrm{BBC}$, 'What is Fracking and Why is It Controversial?', BBC News (27 June 2013), found at: <http://www.bbc.co.uk/news/uk14432401>. A recent poll carried out by The Economist, supported by Statoil found that $51 \%$ of those surveyed disagreed with the statement that the benefits derived from shale gas outweigh the drawbacks of hydraulic fracturing., See 'Join the Debate', The Economist (2 March 2013), found at: <http://www.economist.com/debate/ (2 March 2013
} 
and land by the chemicals used in fracking fluids. ${ }^{4}$ Although fracking fluid is typically more than $99 \%$ water and sand, the United States Environmental Protection Agency cautions that $2-5$ million gallons of water may be necessary to extract the gas or oil in any one operation, and the extractor must thus use tens of thousands of gallons of hazardous chemicals in a single well, much of which will remain deep in the earth after the gas is forced to the surface. ${ }^{5}$ Other concerns include fracking's potential to cause earth tremors - a concern evidenced in recent seismic activity near a test well in Britain. ${ }^{6}$

In the United States, shale gas extracted through the fracking process has had a significant impact on the energy market, with production reaching 4.9 trillion cubic feet (a quarter of the country's total gas output) since 2000. ${ }^{7}$ Europe, too, has considerable reserves (some 639 trillion cubic feet); however, these remain largely untapped. ${ }^{8}$ It is contended that one of the primary reasons for this continental imbalance in extraction levels is America's lengthy history of fuel exploitation, which has fostered an innovative and competitive fuel services industry. In comparison, Europe has few infrastructural or human resources engaged in the energy sector, barring some countries' offshore activities in the North Sea.

America's competitive market has also driven down costs. Deutsche Bank has estimated a single gas well in Europe could cost US\$14 million to sink - three-anda-half times more than its American equivalent. ${ }^{9}$ Low costs in America are aided by the less overt regulation the American industry faces, as well as Europe's lack of large-scale distribution frameworks and open-access rules, making it less attractive and amenable to developments in fuel extraction. ${ }^{10}$ It is thus unsurprising that

\footnotetext{
${ }^{4}$ D.C. Holzman, 'Methane Found in Well Water Near Fracking Sites', 119:7 Environmental Health Perspectives (2011), 289.

${ }^{5}$ Bureau of Oil and Gas Regulation, New York State Department of Environmental Conservation, Preliminary Revised Draft Supplemental Generic Environmental Impact Statement on the Oil and Gas and Mining Regulatory Program (2009), found at: <http://www.dec.ny.gov/ data/dmn/ogprdsgeisfull.pdf $>$, Chapter 6; United States Environmental Protection Agency, Office of Research and Development, Hydraulic Fracturing Research Study (2010), at 1.

${ }^{6} \mathrm{M}$. McCarthy, 'Fracking for Gas Allowed in UK Despite Earthquakes', The Independent (17 April 2012), found at: <http://www independent.co.uk/news/uk/home-news/fracking-for-gas-allowed-inuk-despite-earthquakes-7648265.html>.

${ }^{7}$ By 2035 the proportion could rise to half. See 'Shale Gas in Europe and America: Fracking Here, Fracking There', The Economist (26 November 2011) ('Fracking Here, Fracking There').

${ }^{8} \mathrm{H}$. Rogers, 'Shale Gas: The Unfolding Story', 27:1 Oxford Review of Economic Policy (2011), 117, at 118; 'The Hunt for Shale Gas in Europe', The Economist (3 December 2009) ('The Hunt for Shale Gas').

9 'The Hunt for Shale Gas', n. 8 above.

${ }^{10} \mathrm{lbid}$.

๑) 2014 John Wiley \& Sons Ltd
}

in 2008, at the height of gas extraction activity, 1,600 rigs were in operation in North America while in Europe there were fewer than $150 .{ }^{11}$

However, the disparity in exploitation of shale gas deposits may be changing. Poland, which potentially possesses Europe's largest deposits of shale gas, has sunk test wells and estimates that commercial production will begin in 2014. ${ }^{12}$ France, which potentially has reserves similar to Poland, has imposed a moratorium on fracking while potential dangers are assessed. ${ }^{13}$ French concerns over environmental impacts may be greater than those of their American counterparts due to the region's high population density and the attendant risk of greater disruption to citizens and a greater pool of potential victims were incidents to occur.

The legal framework at play with respect to fuel extraction is also of fundamental relevance in the imbalance in the use of fracking. In the United States, mineral rights are the property of the landowner while in Europe such rights are generally held by the State. ${ }^{14}$ Thus, while American landowners see potential profit, Europeans may not realize the same level of personal gain from discovery and exploitation. In Ireland, for example, individuals with rights to land where oil or gas deposits exist are entitled to one third of the value of the fuel extracted. ${ }^{15}$ Standard American leases oblige extraction firms to continue production regardless of market prices; as a result, landowners continue to receive royalties regardless of the driller turning a profit. ${ }^{16}$ In Europe, no such standard provisions exist.

Although this may paint an unpromising picture for the future of potential fracking industries in Europe, this is not the case. Europeans have reason to be equally concerned as their American counterparts about the security of their energy supply, and its political and economic cost. Currently, many European countries buy gas from Russia - a country whose influence many in Europe would be content to see reduced or removed through securing alternate energy sources. Indeed, such concerns may play a part in Poland, as well as in Ukraine's haste to embrace shale gas exploration and energy independence. They may also lead others, such as Ireland, to begin fracking in order to meet goals for reducing dependency on foreign energy.

\footnotetext{
11 'Fracking Here, Fracking There', n. 7 above.

12 lbid.

${ }^{13} \mathrm{lbid}$

${ }^{14} \mathrm{lbid}$.

${ }^{15}$ Irish Petroleum and Other Minerals Development Act 1960, Section 35. For the full text of the Act, see: <http://www.irishstatutebook .ie/1960/en/act/pub/0007/index.html>.

16 Ibid.
} 


\section{THE RULE IN RYLANDS V. FLETCHER}

\section{THE CASE THAT GAVE RISE TO THE RULE}

The facts of the case from which the rule in Rylands $v$. Fletcher emerged were as follows. Rylands employed contractors to build a reservoir, during the construction of which the contractors discovered a series of disused coal shafts underneath Rylands' land. The contractors chose to continue work rather than backfilling the shafts. Shortly after being filled, the reservoir built for Rylands burst and the water having escaped into the shafts below flooded a neighbouring mine, run by Fletcher, causing damage subsequent to which Fletcher brought an action under negligence. The case on being heard by the court of first instance was resolved in favour of Rylands, ${ }^{17}$ though one judge of the court in a dissenting judgment argued that Fletcher had the right to enjoy his land free of interference from water, and that as a result the defendant was guilty of trespass and nuisance. This dissenting argument was affirmed on appeal by both the Court of Exchequer and the House of Lords, holding that where the occupier of land accrues on it an unnatural substance which then escapes causing damage to the land of another, he will be liable for the damage caused subsequent to such escape.

\section{DEVELOPMENT OF THE RULE}

The rule in Rylands $v$. Fletcher ${ }^{18}$ has subsequently been recognized as a cause of action in its own right in common law. The rule imposes strict liability upon an owner or occupier of land who introduces to, and keeps on, their land anything liable to do damage if it escapes. ${ }^{19}$ The rule's aim, as stated in Transco plc $v$. Stockport Metropolitan Borough Council, ${ }^{20}$ is to require an entrepreneur to provide by insurance or compensation for the risks their enterprise creates, on the basis that their use of land be non-natural, extraordinary or unusual. ${ }^{21}$ This duty's aim - to insure against consequences, remote as well as proximate, attached to the original act of bringing into existence conditions which might eventually do harm - has been criticized and led to the doctrine's fall out of favour during the twentieth century.

Rylands $v$. Fletcher has been disclaimed in various jurisdictions, including Australia, where the High Court

\footnotetext{
${ }^{17}$ Ibid.

${ }^{18}$ Rylands v. Fletcher, n. 1 above.

${ }^{19}$ Ibid., in the judgment of Lord Cranworth.

20 Transco plc v. Stockport Metropolitan Borough Council, [2003]

UKHL 61 ('Transco'), at paragraph 29.

${ }^{21}$ Ibid., at paragraph 11.

(C) 2014 John Wiley \& Sons Ltd
}

chose to extinguish the doctrine's use in their courts with their ruling of Burnie Port Authority $v$. General Jones Pty Ltd. ${ }^{22}$ Within England and Wales, however, Rylands remains valid, although unfavoured, law according to the decisions in Cambridge Water Co Ltd $v$. Eastern Counties Leather plc ${ }^{23}$ and Transco. ${ }^{24} \mathrm{Cam}^{-}$ bridge Water altered the rule by establishing the principle that nuisance claims under Rylands $v$. Fletcher must include a requirement that the damage be foreseeable, with the court further suggesting Rylands was in fact a sub-set of nuisance as opposed to an independent tort. ${ }^{25}$

The facts of Cambridge Water Company are salient in relation to the potential application of Rylands to the escape of fracking fluid. Cambridge Water was responsible for providing water to the inhabitants of Cambridge and the surrounding areas. In 1976, they purchased a borehole to meet rising water demands. It was subsequently found that the borehole had levels of perchloroethene (PCE) exceeding those allowed under European regulations. The PCE was found to have originated in a tannery owned by Eastern Counties Leather.

Cambridge Water thus argued that Eastern Counties Leather was liable in three ways: first, in negligence; second, in nuisance; and third, under the rule in Rylands $v$. Fletcher. In the High Court, the judge dismissed all three of the company's claims, noting that for negligence and nuisance, the damage had to be reasonably foreseeable, per Overseas Tankship, ${ }^{26}$ and that in this case the damage was not. On the third claim, the court held that the use of industrial chemicals was not 'non-natural', given that it was on an industrial site and that, for the claim to succeed under Rylands, the use must be one bringing increased danger to others, and not merely be the ordinary use of the land or a use proper for the general benefit of the community. ${ }^{27}$ This decision was overturned on appeal to the Court of Appeal.

On appeal in the House of Lords, the ruling of the original court - namely, that the rule under Rylands was applicable and the plaintiff's claim was successful - was restored. The House of Lords noted in their judgment that the Court of Appeal's reliance on Ballard $v$. Tomlinson ${ }^{28}$ was erroneous, and suggested that the case

\footnotetext{
22 Burnie Port Authority v. General Jones Pty, [1994] 179 CLR 520.

${ }^{23}$ Cambridge Water Co. Ltd v Eastern Counties Leather plc, [1994] 1 All ER 53 ('Cambridge Water').

${ }^{24}$ Transco, n. 20 above.

${ }^{25}$ A debate eventually laid to rest in Transco, ibid.

${ }^{26}$ Overseas Tankship (UK) Ltd v. Morts Dock and Engineering Co Ltd., [1961] UKPC 1.

27 Ibid.

${ }^{28}$ Ballard v. Tomlinson, [1885] 29 ChD 115.
} 
should be distinguished on its facts. ${ }^{29}$ As a result, the Lords held that the lower court had neither established a rule that there was a right to clear water, nor that there was strict liability attached to that right. ${ }^{30}$ The court also noted, however, that there were similarities between the principle of 'non-natural use' under Rylands and that of the 'reasonable user' in nuisance. It was therefore concluded that 'it would lead to a more coherent body of common law principles if the rule in Rylands were to be regarded essentially as an extension of the law of nuisance'. ${ }^{31}$

In the subsequent case of Transco, the court upheld the rule in Rylands, though under strict limits as to what constituted non-natural use. In this case, the plaintiff took an action under Rylands for damages covering repairs to one of its gas mains after the surrounding ground had been washed away by the escape of significant quantities of water from a leaking water pipe of the council. In the House of Lords, the court held that the escape of large volumes of water from an ordinary pipe did not satisfy the criteria of Rylands, as the transport even of large quantities - of water was neither a dangerous nor an unnatural use under the rule. As a result, the council was not liable. ${ }^{32}$ In the context of environmental law it is a potentially useful legal tool not only for its application through strict liability, but also for the fact that its application is not limited to adjoining occupiers but extends to any person who sustains damage because of the escape. ${ }^{33}$

\section{ROADBLOCKS TO REVIVING RYLANDS}

Perhaps the most overt impediment to the application of the doctrine in circumstances in which fracking is in use can be found in the judgment by the House of Lords in Transco:

[I]t is tempting to see, beneath the surface of the rule, a policy of requiring the costs of a commercial enterprise to be internalised; to require the entrepreneur to provide, by insurance or otherwise, for the risks to others which his enterprise creates. ${ }^{34}$

However, many have considered that the public interest in promoting economic development made it undesirable to hold an entrepreneur liable when he had not

\footnotetext{
29 'Precedent and Analogy in Legal Reasoning', in: The Stanford Encyclopedia of Philosophy (2006), paragraph 2.1.2, found at: <http:// plato.stanford.edu/entries/legal-reas-prec/

index.html\#PreLayDowRul>.

${ }^{30}$ Cambridge Water, n. 23 above, at 7 .

31 Ibid.

32 Transco, n. 20 above, at paragraphs 8-9.

${ }^{33}$ Healy v. Bray UDC, [1962/1963] 3 Ir Jur Rep 9; Mullen v. Forrester, [1921] 2 IR 412.

${ }^{34}$ Transco, n. 20 above, at paragraph 29.

(c) 2014 John Wiley \& Sons Ltd
}

been negligent. ${ }^{35}$ More recently, the English case of Stannard $v$. Gore ${ }^{36}$ has lent support to the hope that Rylands may re-emerge as a remedy for damage and, potentially, as a remedy effects of fracking leaks. ${ }^{37}$ Stannard concerned damage to the claimant's land caused by the 'escape' of a fire which spread through the defendant's premises, fed by the large stack of tyres which the defendant had brought onto the land on which he carried out the business of a motor vehicle tyre supplier and fitter.

The court of first instance held that all requirements of the rule in Rylands were satisfied and accordingly ruled for the claimant. The defendant appealed, and the judge delivered his ruling in the Court of Appeal that although the Fires Prevention (Metropolis) Act 1774 limited a defendant's liability to non-accidental fires: ${ }^{38}$

[W] here a fire arose from something dangerous that the defendant had brought onto his land there could be nothing accidental about any fire that arose as a result, and what became the rule in Rylands $v$ Fletcher continued to apply with full force, although of course it is the fire itself that is the dangerous thing that escapes the defendant's land, rather than whatever caused the fire to arise in the first place. $^{39}$

Delivering his judgment, Lord Ward noted there was thus 'plainly an escape within the meaning of the Rylands $v$. Fletcher rule' and liability thus turned on whether or not Stannard's activities were dangerous and a non-natural use of the land. ${ }^{40}$ Specifically relating to the non-natural use requirement, Ward noted storing and enlarging the tyre storage area was out of the ordinary, was not normal and not routine and thus satisfied the standard. However, two other members of the court, applying the Transco precedent, agreed that the rule in Rylands should not apply and that the court of first instance had erred as it was not the items brought onto Stannard's land (i.e., the tyres) that had escaped. ${ }^{41}$

Lord Etherton noted that it is necessary in cases involving such escapes (in this case of fire) to restate the classic statement of Rylands $v$. Fletcher. However, there is no consensus as to how this should be done. In some of the fire cases it was regarded as sufficient that the defendant brought onto his land something that was (at the time) considered inherently dangerous, such as a train ${ }^{42}$ or a car. ${ }^{43}$ In other cases, such as

\footnotetext{
${ }^{35}$ Wildtree Hotels Ltd v. Harrow London Borough Council, [2001] 2 AC 1, at 8-9 ('Wildtree Hotels').

${ }^{36}$ Mark Stannard (t/a Wyvern Tyres) v. Robert Raymond Harvey Gore, [2012] EWCA Civ 1248.

37 'Wildtree Hotels', n. 36 above, at paragraph 2.

38 lbid., at paragraph 10.

${ }^{39}$ Ibid., at paragraphs 22-23.

40 Ibid.

${ }^{41}$ Ibid. at paragraphs 24-25.

42 Jones v. Festiniog Railway Company, [1868] LR 3 QB 733.

${ }^{43}$ Musgrove v. Pandelis, [1919] 2 KB 43.
} 
Mason v. Levy Auto Parts of England Ltd, ${ }^{44}$ it was the particular danger presented by the flammable nature of the materials brought onto the land by the defendant which was regarded as critical.

The rule in Rylands is recognized by many - notably Binchy ${ }^{45}$ - as instituting a high threshold for claimants to surmount. Coupled, in the context of environmental actions, with the precautionary principle, and the nature of fracking - itself a regulated activity in those jurisdictions where it is performed - the application of Rylands in the context of fracking may seem problematic. However, it is contended that the decision in Stannard may offer some insights into how the rule might be revived.

It is clear from the dicta of Lord Hoffman in Transco that there are only limited situations in which the rule may be successfully pleaded. However, the ruling of the court of first instance in Stannard, though overturned, would seem to offer a potential for the requirements of 'naturalness' of land use and 'danger' to be severed by allowing claims to succeed under Rylands, despite the naturalness of land use not being in question. As such, the heightened risk of the activity or use engaged in, which led to damage pursuant to escape, would trigger a successful use of the rule in an environmental law context. Though Stannard relates to the escape of fire, a similar view might apply to the use of the rule in fracking - in which a license is granted to engage in the activity, and the chemicals used may be naturally occurring but due to the quantities and manner of their use become unnatural, thus inviting the use of the rule in Rylands.

The following section examines the case of Dimock, Pennsylvania and American law relating to escape of dangerous materials which cause damage, before moving on to draw together the scenario presented by this case study, and examining the regulatory context and application of the rule in Rylands to fracking.

\section{CASE STUDY: DIMOCK, PENNSYLVANIA}

In 2008, residents of Dimock, a town in northeastern Pennsylvania in the United States, where fracking is used by Cabot Oil and Gas to collect gas, reported their water had turned brown and was staining crockery and clothing. Residents in close proximity to fracking wells also experienced dizziness while showering. ${ }^{46}$ Subse-

${ }^{44}$ Mason v. Levy Auto Parts of England Ltd, [1967] 2 QB 530 per MacKenna J, at 542.

${ }^{45}$ W. Binchy, 'Recent Developments in the Law of Torts', 4:1 Judicial Studies Institute Journal (2004), 8.

${ }^{46}$ Fiorentino v Cabot \& Gas Corp, 50 F.Supp. 2d. 506 (M.D. Pa. Nov. 15, 2010) ('Fiorentino').

(c) 2014 John Wiley \& Sons Ltd quent tests performed by the Pennsylvania Department of Environmental Protection (DEP) found elevated levels of methane, iron and aluminium in the area's water supply. ${ }^{47}$ There were also allegations that independent investigations had revealed levels of the chemicals trimethylbenzene and toluene exceeding maximum state standards in ground and drinking water in the area..$^{48}$ In nearby Susquehanna County, barium, manganese and strontium were detected in drinking water near fracking wells. ${ }^{49}$

Although methane and small amounts of other chemicals in water are not geologically uncommon in certain areas, including Pennsylvania, the DEP determined that the methane in Dimock's water supplies was thermogenic rather than biogenic in origin, meaning it came from the rock layers beneath the Earth's surface rather than from biological sources such as cattle, and was therefore attributable to Cabot's activity. ${ }^{50}$ The DEP observed 'bubbling gas and high pressure readings from a number of wells that proved poor well construction, and excessive gas levels that could only exist in wells that were leaking' ${ }^{51}$

A year after these events, in 2009, a further series of escapes of fracking fluid occurred in Dimock. ${ }^{2}$ The well's operator, Cabot, used hay bales and earth dams in attempts to contain the spill and determined that migration of the fluid to surface waters was unlikely. ${ }^{53}$ Nevertheless, the fluid reached and contaminated nearby creeks and wetlands and two weeks later an order was issued requiring Cabot to cease its fracking operations. ${ }^{54}$

In the subsequent litigation, Fiorentino $v$. Cabot Oil \& $G a s,{ }^{55}$ the plaintiffs included strict liability among their

${ }^{47}$ C. Bateman, 'A Colossal Fracking Mess', Vanity Fair (21 June 2010), found at: <http://www.vanityfair.com/business/features/2010/ 06/fracking-in-pennsylvania-201006>.

48 See Fiorentino, n. 46 above. These chemicals are also subject to federal reporting requirements. Emergency Planning and Community Right-to-Know Act, 342 USC $\S 313$ (1986). Toluene and many of its derivatives are also subject to the reporting requirements of the Comprehensive Environmental Response, Compensation, and Liability Act, 40 CFR $\$ 302.4$.

${ }^{49}$ L.S. Rubin, 'Frack to the Future: Considering a Strict Liability Standard for Hydraulic Fracturing Activities', 3:1 George Washington Journal of Energy and Environmental Law (2012), 117, at 121.

${ }^{50}$ Press Release, Pennsylvania. Department of Environmental Protection, 'DEP Secretary Issues Open Letter to Citizens of Susquehanna County Community Impacted by Ongoing Gas Migration Issues' (19 October 2010), found at: <http://www.portal.state.pa.us/ portal/server.pt/community/newsroom/14287? $\mathrm{id}=14827$ \&typeid=1 $>$.

${ }^{51}$ See L.S. Rubin, n. 49 above, at 120.

$52 \mathrm{lbid}$.

53 Ibid., at 118. See also URS Corporation, Engineering Study (2009), found at: <http://www.pressconnects.com/assets/pdf/CB1446181016 .PDF>, at $1-3$

${ }^{54}$ Cabot, however, was allowed to resume operations three weeks later. Subsequently, the DEP ordered Cabot to install water treatment systems in several homes and permanently close three wells.

55 See Fiorentino, n. 46 above. 
causes of action, alleging that the chemicals used in fracking fluid are abnormally dangerous. Cabot filed a motion to dismiss the strict liability cause of action for failure to state a claim upon which relief might be granted, arguing that the Superior Court of Pennsylvania had held, as a matter of law, that petroleum-related storage and transmission activities are not abnormally dangerous or ultra hazardous..$^{56}$ The plaintiffs countercontended there was no precedent pertaining to the drilling and operation of gas wells. The judge agreed with the plaintiffs and declined to dismiss the cause of action for strict liability. ${ }^{57}$ Relying on precedents concerning fracking in the county - namely Berish $v$. Southwestern Energy Production Co..$^{8}$ - the court concluded that the determination of whether or not an activity is abnormally dangerous is fact-intensive'. ${ }^{59}$ The Dimock case establishes a promising precedent for use in other common law jurisdictions in Europe through its invocation of the language of abnormally dangerous activities and escape. Although the United States has not and did not explicitly embrace the rule in Rylands $v$. Fletcher as in the United Kingdom and other commonwealth countries, ${ }^{60}$ the judgments in both Berish and Fiorentino would furnish persuasive authority ${ }^{61}$ for the use of the rule in the context of fracking in Europe.

Courts in Oregon, Oklahoma, Louisiana and Washington have also concluded that strict liability concepts may apply to 'inherently' or 'abnormally' dangerous activities carried out on lands which then damage neighbouring property, though they have also not invoked the rule in Rylands directly. ${ }^{62}$ An Oregon court applied strict liability to pesticide drift in the 1961 case of Loe v. Lenhard $t^{63}$ - a judgment reaffirmed in the

\footnotetext{
${ }^{56}$ Memorandum of Law in Support of Defendants' Motion to Dismiss Plaintiffs Second Amended Complaint, Fiorentino, ibid., at 1.

${ }^{58}$ Berish v. Southwestern Energy Production Co., 2011 WL 382420 (MD Pa. 3 February 2011)

${ }^{59} \mathrm{lbid}$.

${ }^{60}$ This is largely attributed to the historical context of the rule development in Europe, which took place in the context of mining. This was an industry on which the United States was highly dependent at the time of the rules' emergence, discouraging the adoption of rules in the United States for fear of a 'chilling effect' on business and industry. See F.C. Woodside III, M.L. Silbersack, T.L. Fliehman and D.J. Feichtner, 'Why Absolute Liability under Rylands v. Fletcher is Absolutely Wrong!', 29:1 Dayton Law Review (2003), 1.

${ }^{61}$ Under common law, previous decisions of higher courts in the jurisdiction are considered binding precedent pursuant to which lower courts are bound to decide. By contrast, foreign precedents or those of lower courts are considered to carry only persuasive authority and courts are not required to consider nor decide in accordance with such decisions. See R. Byrne and P. McCutcheon, Byrne and McCutcheon on the Irish Legal System, $5^{\text {th }}$ edn (Bloomsbury, 2009), at 403 .

62 Bella v. Aurora Air Inc., 279 Or. 13, 566 P 2d 489 (1977); Gotreaux v. Gary, 232 La 373, 94 So 2d 293 (1957); Young v. Darter, 363 P.2d 829 (Okla. 1961)

${ }^{63}$ Loe v. Lenhardt, 227 Or. 242, 362 P.2d 312 (1961).

() 2014 John Wiley \& Sons Ltd
}

1977 case of Bella v. Aurora Air. ${ }^{64}$ The case involved the spraying of 24-D, a pesticide, over broad-leafed crops. ${ }^{65}$ The court stated: '[I]f the activity could be carried out only with a substantially and uncontrollable likelihood that the damage will occur the activity could be classified as abnormally dangerous. ${ }^{96}$

Notwithstanding the financial and industrial considerations that, arguably, make fuel extraction more necessary than crop dusting due to its lack of viable alternatives the escape of fracking fluids presents a situation at least as perilous as the storage of water in large quantities or aerial spreading of pesticide warranting its classification as an ultra-hazardous activity under the rule in Rylands.

For the past 65 years, courts in the United States have refused to apply the common law ad coelunz doctrine, which states that ownership is the same on, above, and below the surface. ${ }^{67}$ This rejection has created a legal regime in which courts generally do not apply the law of trespass to oil and gas cases unless harm takes place on the surface. In Coastal Oil \& Gas Corporation v. Garza Energy Trust, ${ }^{68}$ the Texas Supreme Court found that trespass would apply if chemicals were spilled on the surface, but held that subsurface fracking did not constitute trespass. Similarly, the Kansas Supreme Court held in Crawford v. Hrabe ${ }^{69}$ that a well operator had the right to inject salt water into the ground to increase production and that this injection was not a trespass..$^{70}$ In Crawford, as in Garza, ${ }^{71}$ the Kansas Supreme Court, in holding for the defendants, referred to the economically beneficial nature of drilling..$^{2}$ However, in Starrh Cotton Growers v. Area Energy, ${ }^{73}$ a Californian court held migration of water from an energy company's drilling activities onto cotton-growers' land was a continuing sub-surface trespass. ${ }^{74}$ Similarly, in Beck $v$ Northern Natural Gas Co, ${ }^{75}$ the Tenth Circuit held that

${ }^{64}$ See Bella v Aurora Air Inc., n. 62 above.

${ }^{65}$ C.A. Kennedy, 'Liability in the Aerial Application of Pesticides', 22:1 South Dakota Law Review (1977), 75. See also Boroughs v. Joiner, 337 So. 2d 340 (Ala. 1976) and Christensen v. Midstate Aerial Applicators Corp, 166 N.W.2d 386 (ND 1969).

${ }^{66}$ See Bella v Aurora Air Inc., n. 62 above, at paragraph 24.

${ }^{67}$ United States v. Causby, 328 US 256 (1946).

68 Coastal Oil and Gas Corp USA v. Garza Energy Trust et al., No. 05-0466, 2008 WL 3991029 (Tex. 29 August 2008) ('Coastal Oil and Gas Corp USA').

${ }^{69}$ Steve Crawford, S\&M Oil Company v. Marvin Hrabe, Bruce Krob, Lucille Rogers and Patricia Irey (2002) Kan Sup Ct No 87/624 ('Steve Crawford, S\&M Oil Company').

70 Ibid.

${ }^{71}$ See Justice Willett's concurrence in Coastal Oil and Gas Corp USA, n. 68 above.

${ }^{72}$ See Steve Crawford, S\&M Oil Company, n. 69 above, at paragraph 7.

${ }^{73}$ Starrh \& Starrh Cotton Growers v. Area Energy LLC, [2007] Sup. Ct. No. CV 245287.

${ }^{74}$ Ibid., at 26.

${ }^{75}$ Northern Natural Gas Company v. Tract No. 1062710 et al., Case No. 10-1232-MLB-DWB. 
there was sufficient evidence for a lower court to conclude that the migration of gas from one subsurface formation to another was a trespass. ${ }^{76}$

Finding a common thread in these cases that could have directly appreciable persuasive authority in European common law jurisdictions is difficult. In cases such as Crawford and Garza, courts have adopted a broad interpretation of the rights of mineral lessees and allowed continuation of activities such as underground injection due, in part, to the economic benefits in which they result. Conversely, in cases like Starrh and Beck, courts have held companies responsible for the consequences of water and gas migration. In light of such conflicting rulings, the availability of strict liability under the rule in Rylands, as used in Cabot Oil and Gas, may prove an adept legal tool in cases involving surface and subsurface escape and pollution of water and land.

The ambiguous status of the ad coelunz doctrine, as well as the exemptions fracking currently enjoys from provisions of major national statutes in the United States, including the Clean Air Act, ${ }^{77}$ Clean Water Act $^{78}$ and Safe Drinking Water Act, ${ }^{79}$ leaves significant doubt around the ability of individuals to recover damages through traditional legal avenues in situations such as in Dimock. ${ }^{80}$ Furthermore, if the risks of fracking are as low as its proponents claim, such disparities in fracking's treatment under American legislation are unnecessary; it should be held to standards equal to similar industries.

\section{APPLYING THE RULE IN RYLANDS}

This section examines how current legislative and regulatory provisions are insufficient to cover fracking activities, and how Rylands may be invoked by reference to Ireland where the rule arguably enjoyed the most sustained support and where shale deposits have been located and are the subject of local criticism from public representatives. ${ }^{81}$ The section first considers the existing legal provisions applicable to fracking. It then examines how the rule in Rylands might be invoked in the context of fracking fluids by examining the case law of the jurisdiction which offers binding precedential authority as well as those of other jurisdictions which offer persuasive authority.

\footnotetext{
76 Ibid.

77 Clean Air Act, 42 USC $\S \$ 7401 \mathrm{ff}$. (1970).

78 Clean Water Act, 33 USC §§1251ff. (1972).

${ }^{79}$ Safe Drinking Water Act, 42 USC §300ff. (1974).

80 See comments by M. Brume, Executive Director of the Sierra Club, found at: <http://www.economist.com/debate/days/view/934>.

${ }^{81}$ M. Hennessy and D. Keenan, 'Tax Breaks Encourage Search for Shale Gas; Exploration', Irish Times (21 March 2013).

(c) 2014 John Wiley \& Sons Ltd
}

In 2011, three companies were granted two-year petroleum licensing options by the Irish Department of Communications, Energy and Natural Resources in the midwest and northwest of Ireland. The licenses are for the potential extraction of the deposits of shale gas in those regions through fracking. If fracking were to be undertaken pursuant to such a license at a later date, an integrated pollution prevention control license under the Environmental Protection Agency Act 1992 would be required and the area would be subject to an environmental impact assessment. ${ }^{82}$ Historically, activities held to pose unreasonable risks to the community, which were therefore heavily regulated or precluded, include the storage of explosives, blasting and crop dusting.

In Ireland, three local authorities - the counties of Leitrim, Clare and Roscommon - have sought to ban fracking by including prohibitions in their development plans. However, Convery and Scannell ${ }^{83}$ have noted fundamental difficulties with this approach, as it is potentially illegal following the precedent in Glencar v. Mayo County Council, ${ }^{84}$ in which the court found that a ban on mining previously implemented by Mayo County Council under its development plan was unlawful. ${ }^{85}$

The situation in the United States where fracking is currently banned or allowed on a state-by-state basis will hardly be appropriate in the Irish context, in which environmental policy is set and enforced nationally. However until such time as there is such national policy or legislation, rather than the tacit acceptance of fracking, it would appear that, as in Glencar, local authorities retain the authority to make decisions on grants of permission for such activities in accordance with their development plans and applicable administrative law standards.

Convery and Scannell have further noted that exploration for fuel sources enjoys cross-party support and is essential if Ireland is to reduce its $86 \%$ dependence on imported energy. Thus, although fracking may be unpopular among the public, this may be outweighed by political will to generate economic capital. The government enjoys the liberty to adopt an approach similar to that taken in other European jurisdictions and issue a moratorium or ban on fracking. Until it does so, those

\footnotetext{
${ }^{82}$ D. Healy, Hydraulic Fracturing or 'Fracking': A Short Summary of Current Knowledge and Potential Environmental Impacts (Environmental Protection Agency 2012); and 'No "Fracking" until Further Study, Says Rabbitte', Irish Times (14 May 2012).

${ }^{83} \mathrm{~F}$. Convery and Y. Scannell, 'Fracking and Local Credibility in Ireland' (30 May 2012), found at: <http://www.irishenvironment.com/ commentary/frank-convery-and-yvonne-scannell-fracking-and-localcredibility-in-ireland>.

${ }^{84}$ Glencar Exploration plc v. Mayo County Council, [2002] 1 ILRM 481.

85 Ibid.
} 
engaged in prospecting for natural resources are entitled to have their cases assessed by qualified State bodies on the basis of environmental risk and relevant legal considerations. Unless and until the Oireachtas ${ }^{86}$ takes such actions, there is no power, at a local political level, to refuse permission for fracking. ${ }^{87}$

\section{CURRENT LEGAL PROVISIONS GOVERNING FUEL EXTRACTION IN IRELAND}

\section{The Petroleum and Other Minerals Act}

The policy of successive Irish governments in relation to the extraction of fossil fuels has been to endeavour to attract international corporations to undertake exploration activities. ${ }^{88}$ Under the Petroleum and Other Minerals Act 1960, both oil and gas are defined as 'petroleum', ${ }^{89}$ meaning that fracking activities could presumptively be encompassed by existing legislation. However, difficulties could emerge in relation to imposing liability and claiming compensation for damage under the Act in circumstances where leaks of fracking liquids polluted neighbouring property. The Act imposes liability on the holder of a permit for the exploitation of petroleum ${ }^{90}$ who causes nuisance or damage to surface land or water through their work ${ }^{91}$ on site. However, it makes no express provision for claims by neighbouring property owners and does not provide for compensation. ${ }^{92}$

While such an omission (liability without provision for compensation) may be politically advantageous in providing a degree of superficial assurance for an industry seeking to temporarily locate and explore in Ireland, as well as those who could immediately envisage themselves as claimants, it also creates ambiguity and uncertainty relating to damages and signals a lack of transparency unwelcome in the modern regulatory State. Should fracking begin in Ireland, further regulatory and legislative provisions taking adequate account of the associated risks and protective measures would thus be required.

\footnotetext{
${ }^{86}$ The Irish legislature.

${ }^{87}$ See F. Convery and Y. Scannell, n. 83 above.

${ }^{88}$ See: <http://www.dcenr.gov.ie/Natural/>.

${ }^{89}$ Irish Petroleum and Other Minerals Act 1960, n. 15 above, Section 2.1 reads: 'any mineral, oil or relative hydrocarbon and natural gas and other liquid or gaseous hydrocarbons and their derivatives or constituent substances existing in its natural condition in strata and includes any other mineral substance contained in and natural gas brought to the surface with them in the normal process of extraction'.

${ }^{90}$ Ibid., Section 28.1.

${ }^{91}$ Ibid., Section 16.1-2.

92 Ibid., Section 35.

(c) 2014 John Wiley \& Sons Ltd
}

\section{EU Environmental Liability Directive}

Directive 2004/35 on Environmental Liability ${ }^{93}$ establishes a framework based on the polluter pays principle $^{94}$ to prevent and remedy measurable direct or indirect damage to European sites (and any other sites designated by Member States), water and soil. However, the Directive does not directly address damage to persons or property. Furthermore, individual Member States may afford defences deemed appropriate to operators under Annex III (that are otherwise strictly liable), leading to a situation in which the Directive could be transposed in a sufficiently industryorientated manner so as to make it challenging to succeed in claims for environmental damage.

Under the Directive, the operator whose occupational activity causes the imminent threat or occurrence of environmental damage is liable for the costs incurred in carrying out the preventive or remedial measures required as a result of the threat or damage. ${ }^{95}$ However, as the Environmental Liability Directive deals only with 'pure ecological damage' and is based on administrative penalties as distinct from a civil liability system such as that generally covered under the law of tort, it is unclear whether individual property owners affected would be afforded redress under its auspices. Thus, a need for a means of seeking a remedy for damage to property not covered by the Directive or its implementing legislation remains. This means of redress may be found by employing the rule in Rylands.

\section{REVIVING RYLANDS}

As evidenced by the decision in Glencar, as well as the national and European legislative provisions outlined above, fracking in Ireland remains largely unregulated, with provisions for its regulation implicitly provided for at best and little certainty as to the manner in which damage to property might be redressed should its use commence. In seeking to regulate fracking in the future, the precautionary principle may perhaps offer the most prudent standard of guidance for the development and use of fracking. The principle states that if an action or policy is suspected of presenting a risk of harm to the public or the environment then, in the absence of full scientific certainty, the burden of proof shall fall on those seeking to engage in the activity to disprove suspecting deleterious effects per Article 191.2 of the TFEU. ${ }^{96}$ The principle has, through its application in

\footnotetext{
${ }^{93}$ Directive 2004/35/CE of 21 April 2004 on Environmental Liability with Regard to the Prevention and Remedying of Environmental Damage, [2004] OJ L143/56.

${ }^{94}$ Consolidated Version of the Treaty on the Functioning of the European Union, [2010] OJ C83/47, Article 191.2.

${ }_{95}$ Directive 2004/35/CE, n. 93 above, Article 17.1 and 17.2.

96 Ibid.
} 
case law - notably in the cases of Pfizer ${ }^{97}$ and Dutch Vitamins $^{98}$ - become a 'general principle of EU law' ${ }^{99}$

It is clear from Dutch Vitamins that in exercising their discretion relating to the protection of public health, Member States must comply with the principle of proportionality. The case suggests that, following a risk assessment, if the Member State finds a likelihood of real harm then, based on the precautionary principle, it can ban a good or activity. In the Irish context, the environmental legislation currently in place requires that development plans drawn up by local authorities adequately assess the risks, pursuant to which an environmental impact assessment may be required. ${ }^{100}$

While the precautionary principle may offer guidance for best practices in new regulation or legislation at a national or European level, in cases where fracking is in use it offers little succour to those whose property is damaged through escapes of fracking fluids. The best means of redress, which this article has identified, is the revival of the rule in Rylands for application in situations in which such escapes and damages do occur. The rule in Rylands has been accepted and applied by the Irish courts - notably in Superquinn v. Bray UDC ${ }^{101}$ and has been deemed to include, within the scope of the non-natural use requirement, escapes of methane from landfills, ${ }^{102}$ escapes of large volumes of water, ${ }^{103}$ storage of large quantities or of smaller individual quantities on a large scale, of chemicals, ${ }^{104}$ and sewage ${ }^{105}$ Although the case of Hanrahan $v$. Merck Sharp and Dohme $e^{106}$ might seem to present an impediment to the revival of Rylands, it is contended that Hanrahan should be distinguished on its facts and is thus not applicable to the use of the rule in relation to fracking. The distinguishing facts centre on problems faced by the plaintiffs in

${ }^{97}$ ECJ, Case T-13/99, Pfizer Animal Health v. Council, [2002] ECR II-3305, at paragraph 149. In that case the European Court of Justice (ECJ) established that 'risk assessment includes for the competent public authority . . . a two-fold task . . . first, determining what level of risk is deemed unacceptable and, second, conducting a scientific assessment of the risks'. Ibid. It is thus for the Community institutions to determine the level of protection which they deem appropriate for society and by reference to that level of protection they must then determine the level of risk based on available scientific knowledge.

${ }^{98}$ ECJ, Case C-41/02, Commission v. Netherlands (Dutch Vitamins), [2004] ECR I-11375.

99 M.A. Recuerda Girela, 'Risk and Reason in the European Union Law', 1:5 European Food and Feed Law Review (2006), 270.

100 Irish Planning and Development Act 2000, found at: <http:// www.irishstatutebook.ie/2000/en/act/pub/0030/>, Articles 3, 4.1 and 4.2 .

101 Superquinn v. Bray UDC, [1998] 3 IR 542.

102 Gertsen v. Municipality of Metropolitan Toronto, [1973] DLR (3d) 641.

103 Dockery v. Manor Park Homebuilders Ltd, High Court 10 April 1995 (O'Hanlon J). Cf. Poplar Homes Ltd v. Society of African Missions Trustees, [1997] Ir L Log W 367 (Laffroy J).

${ }^{104}$ Cambridge Water, n. 23 above.

105 Smeaton v. Ilford Corporation, [1954] Ch 450.

${ }^{106}$ Hanrahan v. Merck Sharpe and Dohme (Ireland) Ltd, [1988] IESC 1.

(C) 2014 John Wiley \& Sons Ltd the case in establishing causation and escape. The plaintiffs' claims under Rylands rested primarily on the alleged air pollution by emissions from the defendant's factory, yet establishing both escape and causation proved impossible under Rylands. In the case of fracking, where escape and damage are clearly evidenced by soil and water samples containing unacceptable quantities of chemicals outside the defendant's land, such impediments are surmountable.

The difficulty experienced by the plaintiffs in Hanrahan in establishing causation, and thus proving that the ill health and damage they suffered was due to the defendant's activities, was central to the failure of a cause under Rylands in that case. By contrast, as evidenced in cases such as Fiorentino, in the event of the escape of fracking fluids the presence of the dangerous element is easily established and its effect more easily appreciable. Such precedents that deem the escape of water and methane accumulations to fall under Rylands offer promising potential for the application of the rule in cases where fracking fluid escapes and causes damage. While the English precedents of Transco and Stannard would indicate - for that jurisdiction - a decline in the judiciary's regard of the rule, in Ireland both judgements enjoy only persuasive authority before the courts. In the presence of American cases, such as Fiorentino, which offer persuasive authority, the case for the revival of Rylands in Ireland remains open.

\section{CONCLUSION}

In summer 2013, British Chancellor of the Exchequer George Osborne announced major tax breaks to encourage early investment in shale gas exploration in the United Kingdom following the positive economic impacts of the shale gas boom on the American gas industry and its reduction in fuel prices. ${ }^{107}$ Osborne projected that, by July 2013, the United Kingdom Department for Energy and Climate Change would produce detailed rules to govern exploration for the shale gas discovered in Northern Ireland, Lancashire and southern England. The announcement came soon after a company exploring in Lancashire withdrew its planning application delaying drilling by a year following mild tremors that occurred in the area following fracking activity.

The provision of fuel is of high and increasing social and economic value, yet such benefits must be weighed against the associated risks inherent in the production process. Modern technology has not dealt effectively with accidental spillage - a risk that would appear to be

107 'There's Gold in Them There Wells', The Economist (21 December 2013), found at: <http://www.economist.com/news/christmasspecials/21591748-theres-gold-them-there-wells $>$. 
increasing with the emergence of fracking whose production process carries a high risk of accidental discharges. The explosion at the BP Deepwater Horizon well in the Gulf of Mexico during 2010 intensified calls for sweeping changes in American energy and environmental law and regulation, and heightened global calls for reform of fuel extraction. However, the wideranging changes the incident promised to precipitate have yet to transpire and momentum has, conversely, shifted to a more permissive regime of aggressive oil and gas development with the former regulatory scheme largely intact.

The failure to adapt to changing fuel extraction technologies is unsurprising, as the prevailing legal and policy architecture is designed to withstand changing circumstances, even those as extreme as the BP blowout. Changing or improving safety and environmental stewardship practices, requires concerted and focused action that may only take root after repeated future disasters. ${ }^{108}$ Ireland, which relies so heavily on its natural landscape and environment to attract tourism as well as its industry-friendly policies to attract investment from multinationals, as well as numerous American industries, can ill-afford to suffer from such an imbalance in environmental protection and industrial soft-touch regulation, either in exploiting fuel reserves through traditional methods or through increased use of fracking.

A revival of the rule in Rylands has the potential to maintain the current industry-friendly standards, while providing a powerful deterrent against irresponsible practices through the threat of both monetary and reputational damage. This may serve as the most mutually acceptable resolution to popular fears of damage that cannot be easily remedied before the courts.

The private sector plays a crucial role in the exploitation of the global commons yet its actions also harbour the potential to adversely affect the local and global environment and thus the person and property of citizens. ${ }^{109}$ As more knowledge and understanding is gained in respect of the benefits and risks posed by fuel extraction, national legal and regulatory frameworks must evolve to reflect the rights and responsibility that the parties involved bear. In light of the current absence of explicit regulations, the Rylands rule provides an indispensible tool for those whose use and enjoyment of their land and health is jeopardized or damaged by

\footnotetext{
${ }^{108}$ M. Davis, 'Lessons Unlearned: The Legal and Policy Legacy of the BP Deep-water Horizon Spill', 3:2 Washington and Lee Journal of Energy, Climate and Environment (2012), 155.

${ }^{109}$ A Nolkaemper 'Responsibility of Transnational Corporations in International Environmental Law: Three Perspectives', in: G. Winter (ed.), Multilevel Governance of Global Environmental Changes: Perspectives from Science Sociology and the Law (Cambridge University Press, 2006), 179, at 179-180.
}

(c) 2014 John Wiley \& Sons Ltd non-accidental environmental contamination subsequent to fracking.

Róisín Áine Costello graduated from Trinity College Dublin with a first class honours LLB in 2013. During this time, she served as editor-in-chief and senior editor for the Trinity College Social and Political Review and Trinity College Law Review, respectively, and worked for several public bodies and as a trainee with the Parliamentary Assembly at the Council of Europe. She is currently studying for her MPMP at the Institut d'Études Politiques de Paris, where her research interests focus on the impact of governance and policy on law, specifically in the areas of international trade and communications, health care regulation and environmental policy. She will be spending 2014-2015 pursuing her LLM at the Georgetown Law Centre in Washington, DC, where her specific focus will be on technology law and regulation, in particular how evolving technologies affect international trade and the potential impacts of communications technologies on national and international governance architectures and traditional civil rights. Her previous publications have addressed issues such as climate change and statelessness, Southeast Asian politics and the sale of State assets in Greece. 